Lektor

Institut for Kunst- og Kulturvidenskab, Københavns Universitet

\title{
POSTFASCISMEN, ELLER DEN SENE KAPITALISMES KULTURELLE LOGIK
}

De fleste kan sikkert godt se henvisningen i min titel. Det er Fredric Jamesons klassiske tekst og senere bog om postmodernismen som senkapitalismens kulturelle logik, jeg henviser til. Meget er sket, siden Jamesons tekst blev publiceret i 1984 som et forsøg på at analysere en ny periode (Jameson, Postmodernism). På den ene side fremstår de ophedede debatter for og imod postmodernismen og/eller det postmoderne på mange måder lidt anakronistiske i dag. På den anden side er Jamesons henvisning til "sen-kapitalismen", der længe syntes nærmest latterlig, fordi ingen kunne forestille sig noget andet, kun blevet mere aktuel med finanskrisen. Men fra 1989 og frem til 2007 var der få, der talte om senkapitalisme i betydningen en kriseramt eller endda døende kapitalisme. Selv har Jameson for nyligt skrevet, at det, han dengang forsøgte at analysere og indfange under betegnelsen 'postmodernisme', var globaliseringen eller globaliseringens kulturelle dimension (Jameson, "The Aesthetics" 104). Jamesons analyse var altså en kritisk analyse af en ny global kulturel logik, der havde sat sig igennem i den kulturelle overbygning på en ny etape i den kapitalistiske økonomis historie. Det var pointen med titlen på Jamesons tekst, der elegant pegede tilbage på marxismens basis-overbygnings-model, men også forsøgte at udvide den. 
8 KULTUR \& KLASSE $* 126 * 2018$

DET REAKTIONÆRE

'Senkapitalisme' var en betegnelse, som både den trotskistiske økonom Ernest Mandel og Theodor W. Adorno benyttede i analyser af kapitalismens udvikling i 1960'erne og 1970'erne. Senkapitalismen var en ny periode, der fulgte efter monopolkapitalismen. I sin store afhandling fra 1973 med titlen Der Spätkapitalismus beskriver Mandel de seneste hundrede års historie som udviklingen af den kapitalistiske produktionsmådes iboende modsætninger. I overensstemmelse med de abstrakte bevægelseslove, som Marx opdagede i sin kritik af den politiske økonomi, analyserer Mandel efterkrigstidens voldsomme vækst i den internationale kapitalistiske økonomi, men peger også på vækstens iboende begrænsninger (Mandel 499-526). Jameson fulgte umiddelbart Mandel og Adorno og skrev, at den nye periode begyndte på et tidspunkt efter Anden Verdenskrig, sidst i 1950'erne eller begyndelsen af 1960'erne, om end Jameson tenderede til at bruge senere eksempler, hvorved postmodernisme mere endte som en kritisk beskrivelse af perioden fra midt i 1960'erne og frem med særlig vægt på 1980'erne.

I forlængelse af Mandel og Adorno fokuserede Jameson på krisetendenser. Postmodernismen var en undergangsstemning eller en særlig krisekultur. Jameson startede således sin tekst med en beskrivelse af en række afslutninger. En masse forskellige fænomener er i krise, skrev Jameson: kunst, ideologi og sociale klasser, men også velfærdssamfundet, socialdemokratismen og leninismen (Jameson, Postmodernism 1). I dag er det slående, i hvor høj grad Jameson faktisk havde fat i noget: en række politiske former, begreber og praksisser, der havde været afgørende for etableringen af et moderne borgerligt samfund, var faktisk ved at undergå en forvandling. Men nu skal det ikke i denne sammenhæng handle om postmodernismen som sådan eller Jamesons analyse heraf. Jeg vil ikke kaste mig ud i endnu en diskussion af, hvorvidt postmodernismen var den rigtige læsning af udviklingen. Det skal i stedet handle om de nye reaktionære fænomener, som har indtaget den politiske scene i løbet af de seneste år i Europa og USA, fænomener jeg vil beskrive som postfascistiske. Hensigten med at henvise til Jameson, er at bruge hans forsøg på at beskrive forholdet mellem økonomi og kultur i en kriseramt kapitalisme som et udgangspunkt eller som en analytisk ramme. Jamesons analyse af postmodernismen giver nogle greb, hvormed det er muligt at analysere de reaktionære eller postfascistiske fænomener og forankre dem i en analyse
9 MIKKEL BOLT

POSTFASCISMEN, ELLER DEN SENE KAPITALISMES KULTURELLE...

af ændringer i senkapitalismen. Det skal i det følgende således handle om postfascismen som den sene kapitalismes kulturelle logik. Jeg vil se nærmere på basis såvel som overbygning og forsøge at analysere den sene kapitalisme, men selvfølgelig også analysere postfascismen som den sene kapitalismes kulturelle produktionsmåde.

\section{FRA KLASSEKAMP TIL KULTURKAMP}

Noget af det slående ved de forskellige politiske begivenheder og fænomener, som jeg i forlængelse af den italienske totalitarismehistoriker Enzo Traverso betegner som postfascistiske - Brexit, Trump, AfD, Pegida, Le Pen, Wilders og Dansk Folkeparti - er, i hvor høj grad de er kulturelle, mere end de er økonomiske i snæver forstand (Traverso). Postfascismen er i udpræget grad et kulturelt fænomen. Og samtidens konflikter udspiller sig mindre som regulær klassekamp end som forskellige former for kulturkamp. Det giver selvfølgelig god mening at betragte disse kulturkampe som en art stedfortræderkrige, hvor bagvedliggende økonomiske udviklinger forbliver skjult, men de er mere end det, og de skal i forlængelse af Jamesons analyse af postmodernismen analyseres som symptomer på en mere generel kulturalisering af økonomiske kampe. I senkapitalismen medierer kultur politik og økonomi og foregriber dem endda. Postmodernismen var en beskrivelse af denne udvikling, hvor basis og overbygning, kultur og økonomi smelter sammen på en helt anden måde end tidligere, og hvor kultur tager form af en hel social struktur. Der finder en form for symbolsk appropriation sted, hvor samfundet på en langt mere omfattende måde end tidligere repræsenterer sig selv uden henvisning til noget andet end sig selv. Postmodernismen var denne selv-repræsentation, hvad Guy Debord før Jameson beskrev som det spektakulære eller skuespilsamfundet, hvor hverdagen underkastes en konstant byge af repræsentationer, slogans, jingles, brands, logoer, falske løfter og virtuelle virkeligheder (Debord).

Den politisk-økonomiske baggrund for den nye postfascisme er vigtig, og baggrunden for fremkomsten af den nye form for fascisme er en mere end 30 år lang økonomisk krise, som jeg vil redegøre for senere i artiklen. Men den nye fascisme er netop kendetegnet ved at tilbyde identifikation og identitet hinsides socio-økonomiske kategorier. På den måde er nutidens 
10 KULTUR \& KLASSE $* 126 * 2018$

DET REAKTIONÆRE
11 MIKKEL BOLT

POSTFASCISMEN, ELLER DEN SENE KAPITALISMES KULTURELLE... fascisme postmoderne. Arbejdsløshed, prekarisering og velfærdsstatens langsomme udhuling oversættes til islamofobi og fremmedfrygt. 'Vi bygger en mur, som kan holde immigranterne ude,' tordner Trump. 'Mexicanerne stjæler vores jobs og voldtager vores kvinder, og klimaforandringerne er noget, kineserne har fundet på.' I Europa er det muslimerne, der er problemet: 'Muslimerne oversvømmer Europa og ødelægger vores kultur, udnytter vores velfærdssystem,' raser Wilders, Le Pen og Søren Espersen. Postfascismens succes har i høj grad at gøre med dens evne til at oversætte social (u)retfærdighed til reaktionær identitetspolitik, hvor strukturelle økonomiske lovmæssigheder reduceres til frygtpolitik og let identificerbare fjendebilleder, der gentages igen og igen.

Ifølge Traverso, er postfascismen kendetegnet ved en forestilling om et oprindeligt nationalt fællesskab, der er truet af udefrakommende trusler, der skal fjernes (Traverso 12). Denne grundlæggende fascistiske fortælling er stadigvæk omdrejningspunktet hos politikere som Trump og Marine Le Pen. Men i modsætning til den 'oprindelige' fascisme, mellemkrigstidens fascisme, så er den nationale genfødsel ikke længere et spørgsmål om at suspendere det parlamentariske system og sætte det ud af kraft. Det er derfor, Traverso bruger betegnelsen postfascisme. Postfascismen er ikke, som nazismen eksempelvis var det, en ekstra-parlamentarisk politisk bevægelse. Den tager i stedet form af politiske partier, der kæmper inden for det etablerede parlamentariske system. Postfascismen er på den måde fascister uden fascisme, hvis vi dermed forstår en politisk bevægelse og paramilitære stormtropper, der marcherer rundt i gaderne. Men projektet er stadig centreret omkring etno-nationalistisk eksklusion og revitaliseret økonomisk vækst gennem offentlige investeringer i den nationale industri og militæret.

Holocaust og Anden Verdenskrig har gjort det næsten umuligt for de postfascistiske politikere at præsentere sig som fascister, så selvom vi finder den samme dæmonisering og xenofobi som i mellemkrigstidens fascisme, så afviser de fleste postfascister sammenligningen. Desværre har store dele af pressen og den politiske klasse i de enkelte lande ukritisk accepteret denne afvisning og forsøger i stedet at beskrive de nye fascistiske fænomener som populistiske (Hansen; Müller). Dermed har de været medvirkende til at forlene de postfascistiske partier med politisk legitimitet.
Populisme-betegnelsen duer ikke som analytisk redskab, da den udelukkende fokuserer på politisk stil og helt undlader at analysere relationen til såvel nationaldemokrati som kapitalisme (Fassin; Laqueur; Traverso 20). Uden kapitalismekritik er de postfascistiske fænomener imidlertid uforståelige. Troen på nationaldemokratiets styrke har åbnet døren for fascistiske positioner, der dermed har kunnet iklæde sig en demokratisk sprogdragt og deltage i kampen om vælgernes gunst. Konsekvensen har stort set alle steder været et markant ryk til højre på den politiske skala. Dette har vi for eksempel set i Danmark, hvor kampen om de racistiske stemmer endegyldigt har synliggjort folkestyrets etno-nationalistiske indhold. I dag er det danske socialdemokrati lige så racistisk som Dansk Folkeparti og kæmper om førsteretten til at vanskeliggøre indvandring og stigmatisere bestemte befolkningsgrupper fra muslimer til romaer.

Forvandlingen fra fascistiske bevægelser til politiske partier er central for Traversos definition af postfascisme. Rassemblement National er et godt eksempel på denne udvikling. Partiet er gået fra at være et subversivt anti-parti med tydelige forbindelser til den franske fascisme og modkolonialiseringsbevægelse til at blive et alternativ inden for det etablerede politiske system, et parti hvis leder når til anden valgrunde og konkurrerer om at blive præsident i Frankrig. De post-fascistiske partiers retorik er selvfølgelig fremdeles, at den politiske elite ikke duer, at den ikke beskytter folket, men lader multinationale firmaer flytte arbejdspladser rundt efter forgodtbefindende og endnu værre tillader store masser af immigranter at komme til landet, selvom de ikke kan integreres og i virkeligheden vil ødelægge det nationale fællesskab. Men i modsætning til tidligere fascismer præsenterer post-fascismen sit projekt som en fortsættelse snarere end som et brud, den er kendetegnet ved "synkronicitetsnostalgi" (Toscano). Le Pen vil beskytte republikken, ikke ødelægge den. Opgaven er at genskabe republikken som et nationalt fællesskab. "Make America Great Again," som Trump siger. Eller "Gi' os Danmark tilbage," som Dansk Folkeparti siger. Underforstået, at der er udefrakommende trusler, vi skal værne os mod. Som det blev ekspliciteret på en DF-valgplakat i 2001 med et billede af en lyshåret pige og teksten: "Når hun går på efterløn, er der muslimsk flertal i Danmark."

De post-fascistiske politikere præsenterer sig selvfølgelig alle sammen som et brud med den herskende politiske klasse, det være sig Washington DC 
12 KULTUR \& KLASSE $* 126 * 2018$ DET REAKTIONÆRE
13 MIKKEL BOLT

POSTFASCISMEN, ELLER DEN SENE KAPITALISMES KULTURELLE .. eller Christiansborg, men ikke som en revolution, som Mussolini og Hitler gjorde det i 1920'erne og 1930'erne. Det er denne gradvise forvandling, som ligger til grund for Traversos idé om post-fascisme, at fascismen så at sige afklæder sig sin (kontra)revolutionære dragt. Såvel Mussolini som Hitler præsenterede sig som revolutionære mod revolutionen, altså den russiske revolution og truslen om en kommunistisk verdensrevolution. Konteksten er imidlertid en anden i dag. $\mathrm{Nu}$ handler det om at vende tilbage til efterkrigstidens vækst, sikkerhed og velfærd. Vi finder i alle de forskellige postfascistiske partier og politikere forestillingen om en mere simpel verden uden globalisering.

Post-fascismen er derfor ikke systemomvæltende, som fascismen var det ifølge Traverso, men den tager stadig form af nationalistisk og racistisk eksklusion. Hvis den gamle fascisme var kendetegnet ved antisemitisme, i udpræget grad nazismen, så er den nye postfascisme ifølge Traverso først og fremmest islamofobisk (Traverso 78-101). Trump, Wilders, Le Pen og Pia Kjærsgaard er alle islamofober, og de spiller effektivt på truslen fra en militant islamisme, som blæses totalt ud af proportioner. Der var større risiko for at miste livet i 1970'ernes såkaldte 'røde' eller 'sorte' terrorisme end ved et islamistisk terrorangreb i dag. Denne nye islamofobi rammer så alle afrikanere og arabere i Vesten, inklusive ikke-praktiserende muslimer.

I den islamofobiske diskurs antager islam skikkelse af en konspiration. Det er ikke bare en religion, men den del af befolkningen, der skal ekskluderes, den indre fjende, der står i ledtog med det nationale fællesskabs ydre fjender. Frygtpolitikken kender ingen grænser, og mennesker, der flygter fra krig eller migrerer for at få et bedre liv, bliver til fjenden selv, en trussel mod vores identitet, en trussel mod det nationale fællesskab. I den postfascistiske diskurs konkretiseres muslimer som et komplekst sammenfald af økonomisk nedgang og klimakrise, de er den neoliberale nødlandings ansigt.

\section{POSTFASCISMENS ‘SANDHED’}

Der er selvfølgelig noget om snakken, postfascismen er en kulturel oversættelse af en længerevarende politisk-økonomisk udvikling. De hadefulde og xenofobiske tirader - "det amerikanske blodbad stopper her" (Donald
Trump 2016), "Holland er et sygt samfund" (Geert Wilders 2016), "hvor islam trænger frem, følger ørkenen med" (Søren Espersen 2007), "den vestlige kultur er truet af indre opløsning og mangel på selvrespekt" (Marie Krarup 2013) - indeholder faktisk en 'sandhed', hvis man kan kalde den det. Nemlig at der er sket et skifte, i hvilket kapitalen har forsøgt at selvstændiggøre sig fra arbejdet. Baggrunden for det postfascistiske backlash er det først for alvor nyligt registrerede skifte fra en voksende økonomi i efterkrigstidens tre første årtier til en langsomt indsnævrende økonomi de seneste 30-35 år globalt og lokalt.

Den samfundsmæssige konsensus i såvel USA som i Vesteuropa var i perioden efter Anden Verdenskrig kendetegnet af drømmen om vækst og adgang til flere materielle goder. De generationer, der voksende op i efterkrigstiden, blev lovet et bedre liv end deres forældre. Det er denne "magelighedens revolution", som Erling Bjøl kalder den, som postfascisterne henviser til og kræver genetableret. Arbejderklasserne i USA og Vesteuropa blev lovet om ikke guld og grønne skove, så i det mindste gratis eller billig uddannelse, boliger og kulturtilbud og adgang til en hel verden af nye forbrugsgenstande, som de kunne erhverve sig takket være deres støt stigende lønninger fra fast arbejde. Det politisk-økonomiske fundament for denne drøm begyndte allerede at erodere i begyndelsen af 1970'erne, men det var først med finanskrisen, at eroderingen i retrospektiv blev synlig.

I en periode frem til 2007 blev drømmen nemlig delvist opretholdt af billige lån, men siden da er gassen gået af den finanskapitalistiske ballon. Drømmen er blevet til en reaktionær fantasi om en muslimsk invasion. Neoliberale spareprogrammer og ditto skattelettelser for firmaer og de rige har været den politiske virkelighed siden begyndelsen af 1980'erne i de fleste vestlige lande, og det ændrede finanskrisen ikke på, den accelererede blot tendensen. Denne proces, hvor national velfærd blev erstattet af neoliberal udligning til fordel for de rige, har udhulet efterkrigstidens statsstyrede moderniseringsprojekter og efterladt den vestlige arbejderklasse rodløs. Som en rapport fra McKinsey Global Institute fra juli 2016 anfører, er der for første gang udsigt til, at unge i 25 såkaldte avancerede økonomier "bliver fattigere end deres forældre" (McKinsey). Efter Brexit og Trump er det "globaliseringens negative konsekvenser', som politiske kommentatorer pludselig har travlt med at tale om. TINA-doktrinen er endt med at fremmedgøre store 
14 KULTUR \& KLASSE $* 126 * 2018$ DET REAKTIONÆRE
15 MIKKEL BOLT

POSTFASCISMEN, ELLER DEN SENE KAPITALISMES KULTURELLE... dele af befolkningerne i kapitalens (tidligere) centrum, og nu afreagerer det globale arbejderaristokrati ved at slutte op bag (selv)destruktive nationalistiske projekter (Ghosh). Drømmen om ubegrænset vækst og større forbrug har pludselig vist sig at være en løgn. ${ }^{1}$

Det er postfascismens 'sandhed'. Det er dét, den registrerer. Den afslører, at noget er forbi. Det var det 'afslørende' i Trumps "Make America Great Again," hvor pointen selvfølgelig er again, altså en konstatering at USA eller det autentiske hvide amerikanske fællesskab, som Trump taler om, ikke længere er stort og sejrrigt, men tværtimod er ved at falde fra hinanden. Postfascisterne peger faktisk på noget, men kortslutter så selvfølgelig med det samme analysen og mobiliserer desillusionerede hvide (mandlige) vælgere mod imaginære indre og ydre fjender, først og fremmest immigranter og flygtninge (for hvem det nedbrudte vestlige samfund selvfølgelig endnu tilbyder noget bedre end borgerkrig eller brutal kapitalistisk (under)udvikling).

De postfascistiske partier appellerer generelt til den lavere middelklasse og dele af den hvide arbejderklasse. Det er tilfældet i såvel USA som Storbritannien, Holland, Tyskland, Danmark, Frankrig og Italien. Det var således den lavere middelklasse og visse dele af den hvide arbejderklasse i det midt-vestlige, landlige USA, men også i områder som Florida og Las Vegas, der mest entusiastisk støttede op om Trump. De, der har små virksomheder og ejer fast ejendom, og som tabte på 2008-krisen, hvor værdien af deres huse pludseligt blev halveret. Billedet er det samme i Vesteuropa, i Tyskland, Holland og Frankrig. Det er de såkaldte Wutbürgere, der udgør postfascismens vælgermæssige kerne. Historisk har den lavere middelklasse ofte vist sig som "det moderne samfunds bagtrop" (Wright Mills). De er til fals for politiske løfter om retning i en kaotisk situation, hvor de risikerer at miste tidligere tilkæmpede privilegier. Wright Mills beskriver den lavere middelklasse som en reaktiv gruppe, der hellere vil skrue tiden

1 Eller under så stort pres, at det er nødvendigt at 'stramme op' og lukke grænserne. Vi vil have en mur eller vi vil have grænsebomme. "Vi lever i et fantastisk land. Vi lever i Danmark. [...] Derfor skal vi sikre Danmark, vi skal sikre vores samfund. Det gør vi blandt andet ved at sætte grænser. [...] Vi skal simpelthen sørge for, at danskerne er herrer i eget hus", som Kristian Thulesen Dahl siger i en DF-video fra 2017; https://www.youtube.com/watch?v=Qy40CAd55Ew tilbage end gå forrest i et egentligt opgør med den herskende orden (Wright Mills 352). Det var også tilfældet i mellemkrigstiden, hvor småborgerskabet spillede en afgørende rolle i fremkomsten af fascismen. Som Trotskij formulerer det, var "de desperate og forarmede småborgere" "fascismens udgangsbasis" (Trotskij 44). Under 1930'ernes krise mobiliserede den tyske fascisme småborgerskabet, da de via propaganda "piskede et hvidglødende raseri frem hos småborgerskabet og vendte dets had og desperation mod proletariatet" (Trotskij 48).

Ifølge den tyske historiker Annette Leppert-Fögen udtrykker småborgerskabet, eller hvad hun kalder "den deklasserede klasse", en "forældet antikapitalisme", der indtil et vist tidspunkt var historisk sammenfaldende med proletariatets revolutionære kritik af borgerskabet og den kapitalistiske udbytning. Småborgerskabets antikapitalisme er imidlertid motiveret af et ønske om at vende tilbage til en tidligere produktionsform, og kritikken af kapitalismen forbliver derfor moralsk og udelukkende fokuseret på cirkulationssfæren uden forståelse for kapitalakkumulationen (Leppert-Fögen). Kapitalismen er ond, fordi den ødelægger samfundets naturlige orden (hvor den hvide cis-kønnede heteroseksuelle mand bestemmer). Som historikeren Arno Mayer skriver, er middelklassen en plastisk størrelse, der ofte er den "kritiske svinggruppe" i kampen om kontrollen med den moderne stat. Men den har ikke en decideret politik, den er en klasse i-sig, ikke en klasse for-sig, som han skriver (Mayer 418).

Parallellen til nutidens deklasserede småborgere i Saxen, i Sønderjylland, i Skåne, West Midlands, i Didier Eribons Reims og i Iowa i USA er slående. ${ }^{2}$ Her har vi en belejret, tidligere dominerende etnisk majoritet, som føler, de er ved at miste 'deres land', og derfor vil tilbage til en oprindelig orden. De opfatter sig som ofre for den historiske udvikling. En privilegeret gruppe ser sine privilegier forsvinde, men modsætter sig processen

2 I sin erindringsbog Retour à Reims beskriver den franske filosof Didier Eribon hvordan en tidligere arbejderklassekultur er gået i opløsning, og hvilke konsekvenser det har haft i Paris, men især uden for Paris i Frankrig, specifikt i han fødeby Reims. Eribons historiske analyse viser, hvordan arbejderen ikke længere er en figur, som politikere taler om og til. Det har skabt et vakuum. Et vakuum som er blevet udnyttet af Front National, der tilbyder at erstatte arbejderklassen med nationen som identifikationspunkt. 
16 KULTUR \& KLASSE $* 126 * 2018$ DET REAKTIONÆRE
17 MIKKEL BOLT

POSTFASCISMEN, ELLER DEN SENE KAPITALISMES KULTURELLE... på selvdestruktiv og forvrænget vis ved at lange ud efter flygtninge og immigranter, der iscenesættes som en trussel mod et imaginært etno-nationalt fællesskab. Nu skal der strammes op, vi må forskanse os og bygge mure. "Der er så meget, vi skal passe på," som DF siger. Modsvaret på alle truslerne bliver at insistere på genetableringen af et naturligt hierarki. Med Leppert-Fögens termer er (post)fascismen en "småborgerlig revolte" (264).

\section{ABSURD TEATER}

Postfascismen er en kulturalisering af underliggende økonomiske udviklinger. Det er derfor, den på mange måder mere er overbygning end basis. Men, og det er vigtigt, vi skal ikke bare analysere postfascismen ved at vende tilbage til basis. Overbygningen afspejler ikke basis 1 til 1 . Hvis det var tilfældet, kunne vi bare hele tiden tilbageføre ethvert racistisk udsagn til socio-økonomiske forhold og så stoppe analysen dér - når nogen råber noget racistisk eller fra en motorvejsbro på Lolland spytter på flygtninge fra Syrien, er de i virkeligheden bare bekymrede for deres økonomi. De hvide arbejderes ideologi er bare en afspejling af 'virkelige forhold', de ikke har gennemskuet.

Kulturaliseringen har en betydning, og det er nødvendigt at forklare, hvorfor postfascismens racistiske 'oversættelse' af socio-økonomisk deroute fungerer bedre end en marxistisk analyse af 'de virkelige forhold'. Det er nødvendigt at analysere, hvorfor postfascismen fungerer, og hvorfor venstreorienteret politik, som vi kender den fra det 20. århundrede i dens forskellige former, fra leninisme til socialdemokratisme, ikke længere formår at appellere til ret mange vælgere.

I den nuværende situation er forbindelsen mellem klasse og politisk repræsentation svær at kortlægge, alt er så at sige blevet mediering. Trump er det oplagte eksempel. Der er ikke tvivl om, at Trump repræsenterer visse dele af den amerikanske kapitalistklasse, dels de fraktioner der har tabt på globaliseringen, dels det militært-industrielle kompleks, inklusive overvågning og fængsler. Men store dele af det amerikanske erhvervsliv foretrak helt åbenbart Clinton. Og Trumps økonomiske politik vil på ingen måde hjælpe de hvide arbejdere, der stemte på ham, men alligevel stemte de på Trump. Det er den relative autonomisering, vi skal analysere.
Det politiske har selvstændiggjort sig og forvandlet sig til en art absurd teater, hvor Trump som en anden Ubu roi fjoller rundt i en forskudt parallelvirkelighed. $\mathrm{Nu}$ er provokationer og kritik ikke blot noget, det senkapitalistiske samfund i virkeligheden ønsker (og ernærer sig af), nu er staten selv blevet subversiv og skandaløs. Uforskammet afsublimering er nu officiel regeringsmåde i USA (og 'almindelig' oppositionspolitik i Europa). Lawrence Grossberg kalder det for "barokt kaos" og skriver, at Trumps kamp mod massemedierne, brug af 'alternative facts' og evnen til hele tiden at overraske skaber "en form for barok assemblage, hvis umiddelbare effekt er en overvældende følelse af kaos" (Grossberg 126).

På sin vis er Trump en næsten tragikomisk bekræftelse af August Thalheimers gamle diktum, at fascismen redder borgerskabet (økonomisk), men voldtager det (politisk), (Thalheimer 117). Trump skal nok beskytte de kapitalistiske ejendomsforhold og profitter og sikrer dermed kapitalen, men han er ikke ren og skær agent for den amerikanske kapital. Snarere er politik og økonomi blevet delvist adskilt, og Trump kører et politisk show, der om ikke andet underholdningsmæssigt, hvis ikke økonomisk, skal tilgodese den lavere middelklasse, der stemte på ham. Selvom både Bannon og Kushner er gledet i baggrunden, så balancerer Trump stadigvæk mellem den hvide racistiske middelklasse, som alt-right-bevægelsen blot er det mest hysteriske eksempel på, og så de plutokratiske interesser, Kushner repræsenterer. Med Walter Benjamins formulering lader Trump den lavere middelklasse "komme til udtryk" og giver så store skattelettelser til erhvervslivet (Benjamin 157).

Massen kommer til udtryk, nu er det sjovt at være racist, og politik bliver til pop. Eller til et crazy eventyr, hvor alt kan ske. Vi får det bedste fra underholdningens forførende og afskyvækkende verden, sportens fanatiske fankultur, musikkens idoldyrkelse, tegneseriens overtydelighed og tv-seriernes bingemæssighed. Senkapitalismens tyndslidte monader interpelleres af Trumps etno-nationalistiske opråb og fjollede gestus. Med Trump har det politiske selvstændiggjort sig og er blevet til et altomfattende og altopslugende reality-show. Nu er politik mindre partier med programmer og mål og principper, end det er en stemning (Taibbi). Som den tyske kulturkritiker George Seeßlen skriver, kan Trump på den måde forstås som den politiske realisering af amerikansk popkultur, hvor Trump er the 
18 KULTUR \& KLASSE $* 126 * 2018$ DET REAKTIONÆRE
19 MIKKEL BOLT

POSTFASCISMEN, ELLER DEN SENE KAPITALISMES KULTURELLE ... selfmade man, der kæmper mod systemet, besejrer det og bliver folkets helt, befrier folket og genskaber en naturlig orden (Seeßlen).

$\mathrm{Nu}$ er fascismen trådt ind i det 21. århundredes udvidede underholdningssamfund, dens nationalistiske myte fortælles ikke længere som stort iscenesatte partidage i Nürnberg, men som et konstant bombardement af Tweets og breaking news-historier. Trumps Tweets passer perfekt til senkapitalismens forarmede og infantiliserede offentlighed, der intet har at gøre med kommunikativ rationalitet eller universalitet, men derimod er kendetegnet ved religiøs overtro og videnskabelig analfabetisme. Det er skuespilsamfundet, hvor det sociale er blevet så tyndslidt, at det kun med nød og næppe holdes sammen af idiotiske moder, panisk skræk og dumme billeder, det er fællesskabet som simulakrum, hvor sentimental genfortryllelse er den tynde fernis, der endnu holder et smadret kapitalistiske klassesamfund sammen. Trumps etno-nationalisme taler således til individer, hvis subjektiviteter er blevet forvandlet til små salgbare afhængigheder. Postfascismen har på den måde kastet den 'gamle' fascismes alvorsfuldhed til side til fordel for let underholdning. Postfascismen er meget mere loose og afslappet, den er fun, den længes ikke tilbage til det gamle Rom og vil ikke skabe et tusindårsrige, det er bare efterkrigstidens fordistiske massesamfund, der er utopien.

\section{ÆSTETISERING AF POLITIKKEN}

Evnen til at forvandle politik til et show var allerede Walter Benjamins analyse af mellemkrigstidens fascisme. "Fascismen æstetiserer politikken," skrev Benjamin konkluderende i kunstværk-essayet (Benjamin 158). Fascismens fremmedgørende og manipulerende brug af film og radio ødelagde de moderne massemediers demokratiske potentiale. Den tyske fascisme bremsede en potentielt frigørende af-auratisering af kunsten og genanvendte forældede æstetiske begreber som skaberkraft og genialitet til at etablere et anakronistisk æstetisk-politisk regime, der uundgåeligt måtte kulminere i krig, skrev Benjamin. Nazismen forstod, at det politiske var i færd med at ændre sig og blive til noget andet, at det politiske var blevet til massepolitik. Ved hjælp af nye reproduktionsteknologier som filmen og radioen formgav nazismen masserne. "Fascismen forsøger at organisere de nyligt proletariserede masser uden at antaste de ejendomsforhold, som de presser på for at afskaffe. Den ser sin frelse i at lade masserne komme til udtryk (men absolut ikke deres ret)" (Benjamin 156-157). Benjamin forstår fascismen som et resultat af omvæltninger i overbygningen. Det er derfor, han bestemmer fascismen som en æstetisering af politikken. Fascismen ændrer jo ikke økonomien, men opretholder netop den private ejendomsret. Det er Benjamins marxistiske analyse af fascismen som en æstetisk-politisk kontrarevolution. Masserne gives et udtryk, i nazismen er dette udtryk antisemitismen, men uden at kapitalen antastes. Nazismen fastholder masserne som en hob, og deres solidaritetsfølelse og klassebevidsthed ødelægges, hvorved døren til udryddelsen af folkets fjender (men også i sidste ende folket selv) åbnes.

Fascismen 'udfordrer' Benjamin, fordi den ikke ulig de (anti)kunstneriske avantgarder, som Benjamin var allieret med, problematiserer modernitetens diskursive uddifferentiering (Hewitt). Den æstetiserer politikken - forældede kunstbegreber er nu politiske kriterier (Benjamin 130) - og bruger de nye reproduktionsteknologier til at skabe en anden virkelighed ved siden af den (marxistisk-bestemte) virkelighed, som Benjamin tager udgangspunkt i og vil ændre. Det er udfordringen ved fascismen, at den ikke blot mimer avantgarden og den kommunistiske revolution, approprierer dens stil og udtryk, dens kapitalismekritik og organiseringsformer, fascismen er hvad den tyske kulturteoretiker Rainer Stollmann kalder en "erstatningssocialisme" (Stollmann 84), men den afviser også eller forskyder selve basis-overbygnings-modellen og skaber en fascistisk pseudo-virkelighed. Som Benjamin skriver, kommer masserne faktisk til udtryk.

Benjamin kritiserer ganske vist fascismen for at skabe en falsk forening af æstetik og politik, da den ikke ændrer ved de grundlæggende materielle vilkår og blot forlener virkeligheden med ein schöner Schein, men den udfordrer faktisk - det er udfordringen - den kapitalistiske modernitets autonomiseringsproces og mobiliserer massen, giver den et udtryk, foranstalter en selvstændiggørelse af politikken. Fascismen registrerer den kapitalistiske modernitets destruktion, men forstærker den selvfølgelig blot, det kan Benjamin sagtens se. Og den løser således modsætningen mellem produktivkræfter og produktionsforhold gennem en autonomisering af teknikken, der kulminerer i krigens massedrab, hvor folket eller 
20 KULTUR \& KLASSE $* 126 * 2018$ DET REAKTIONÆRE
21 MIKKEL BOLT

POSTFASCISMEN, ELLER DEN SENE KAPITALISMES KULTURELLE... racen giver sig selv form gennem industrialiseret massedrab. Fascismen forsøger at løse modsætninger, der økonomisk set er uløselige inden for kapitalismen, ved hjælp af ekstra-økonomiske kræfter og imperialistisk krig og racedrab. Det er det, Benjamin beskriver som en æstetisering af politikken.

Det er umuligt ikke at se Trump som en nutidig eksponent for en sådan æstetisering. Trump har formået at skabe en massemedievirkelighed, der mere eller mindre har erstattet den politisk-økonomiske virkelighed, vi kender som det politiske (men som selvfølgelig allerede var et skuespil (Debord) eller en politisk repræsentation (Manow)). Det er, som om Trump har forvandlet det politiske til en sæbeopera eller gjort det til et underholdningsshow, hvor der ikke synes at være en ende på de overraskende drejninger, historien kan tage. Trump er det politiske modstykke til Games of Thrones, der formår at kombinere fantasy med soft porno, Shakespeare og gigantiske slagscener i et overflødighedshorn af plots og effekter. Og ligesom med tv-serien bliver det tilsyneladende også bare bedre og bedre og mere og mere outreret. Fra grab-'em-by-the-pussy til Trumps skattesag til Russiagate, Nordstrom-sagen, til "de fine folk" i Charlottesville, Bowling Green-massakren, "min atomknap er større end din" og videre til Stormy Daniels-showet, told på stål, afbrydelsen af Iran-aftalen, Trump bliver bare ved med at overraske.

Som Benjamin er vi konfronteret med en fascisme, der har approprieret taktikker og greb fra dens modstander. Hvis Trump fremstår som en dada-præsident, der har forvandlet politik til fjolleri og provokationer, så fremstår den såkaldte alt-right-bevægelse, der samler en indtil da ret spredt gruppe af white supremacists, anti-feminister, islamofober og antisemiter, som en aktivistisk avantgardegruppe, der lægger sig ud med det kulturelle system og bruger sarkasme og ironi i en kritik af den udbredte undertrykkelse, de mener, hvide mænd er ofre for. I en paradoksal omvending af identitetspolitik tilfalder rollen som den forfulgte nu den hvide mand, der er blevet feminiseret og har mistet sin naturlige styrke. I USA huserer alt-right-bevægelsen, i Tyskland argumenterer den såkaldte avantgarde-konservatisme med Sloterdijk-elev Marc Jongen i spidsen for, at Tyskland har mistet thymos (altså ånd, stolthed og vrede) på grund af indvandring, i England promoverer den såkaldte højre-accelerationisme en frisættelse af kapitalistisk udvikling og skabelsen af en transhuman (hvid) mesterrace, og i Frankrig går de identitære på gaden i forsvar for "rent fransk blod".

Som blandt andre Angela Nagle har bekrevet, har de nye postfascistiske modbevægelser tilegnet sig en stil, som vi almindeligvis finder på den mere eksperimenterende del af den politiske venstrefløj eller i 1960'ernes modkultur (Nagle). Nu er alternativet imidlertid fascistisk. Modkulturen er reaktionær. Vi har på den måde at gøre med en avantgarde fra højre (hvis vi bruger den forældede venstre-højre-distinktion), hvor alt-right-bevægelsen er børn af den italienske futurisme, der jo startede som glødende nationalister og endte som støtter af Mussolinis fascisme (Braun). Som Benjamin er vi konfronteret med et fænomen, der kombinerer en 'progressiv' og 'samtidig' æstetik med en fascistisk ideologi. Alt-right-bevægelsens dude-bro provokationsæstetik er Marinetti 100 år senere, racisme og misogyni er stadigvæk indholdet, nu er indpakningen post-internet og aktionsformen direkte aktioner og mediestunts à la Yes Men og 1990'ernes taktiske mediekunst.

\section{VIRKELIGHEDSFLUGT}

Den tømning af det politiske, der finder sted med Trump, hvor politik som fornuftsbaseret økonomisk-politisk diskurs erstattes af underholdning, er selvfølgelig en form for virkelighedsflugt, om end ikke som forfalskning af en politisk normalitet. Ikke mindst fordi den normalitet, som Clinton og Obama repræsenterer, jo netop allerede er deportationer og droneangreb og neoliberal udhuling af velfærdsstaten. Opgaven må være at tage forskydningen seriøst og forsøge at analysere Trumps 'virkelighedsflugt', analysere den diskursive virkelighed, som postfascismen skaber. Som Ernst Bloch formulerede det om nazismen, blev "den falske bevidsthed om situationen" på en eller anden måde til en "virkelighed", der ikke bare kan afvises som falsk eller som skinvirkelighed (Bloch 196). Og millioner af amerikanere købte jo Trumps forvandling af politik til et show og stemte på ham, og selv de, der ikke kan fordrage Trump, forsøger stakåndet at følge med i de nyeste udviklinger. "Ideologiens materialisering", kalder situationisterne det. "Dér hvor den virkelige verden forandrer sig til simple billeder, bliver 
22 KULTUR \& KLASSE $* 126 * 2018$ DET REAKTIONÆRE
23 MIKKEL BOLT

POSTFASCISMEN, ELLER DEN SENE KAPITALISMES KULTURELLE ... de simple billeder virkelige eksistenser samt de effektive motivationer for en hypnotisk adfærd" (Debord 15).

Som Seßlen skriver, har Trump koloniseret den politiske offentlighed og forvandlet den til et popkulturelt event. Den franske filosof Jean-Pierre Faye beskriver fascismen som "et diskursivt regime" (Faye). Det er det, vi ser med Trump, der mere er et kulturelt fænomen end noget andet. Han er den foreløbige kulmination på den diskursivering eller æstetisering, der har fundet sted med politik i den anden halvdel af det 20. århundrede, hvor politik i stadig højere grad har taget form af repræsentationer, er blevet til billedpolitik. Ikke blot bruger politikere billeder og repræsentationer i præsentationen af deres politiske programmer, politiske begivenheder er blevet egentlige billedbegivenheder, eksemplarisk med 9/11 og terrorangrebet på World Trade Center og Pentagon, men i høj grad også den efterfølgende krig, hvor USA desperat og lettere kaotisk forsøgte at skabe et billede af amerikansk suverænitet (Retort).

For Benjamin var pointen ikke blot at afvise fascismen og den virkelighed, den skabte, men nødvendigheden af at analysere den indefra og udfordre dens konstruktion af en anden virkelighed. Det var ikke nok bare at sige, det var en skinvirkelighed, at fascismen i virkeligheden ikke overvandt det kapitalistiske klassesamfunds grundlæggende modsætninger. Opgaven er at analysere den virkelighed, fascismen skaber i en kompleks sammenføjning af præbevidste interesser og ubevidst begær, som Reich også beskæftigede sig med i sin analyse af fascismen som massepsykologi. Der er netop ikke blot tale om en privat psykisk virkelighedsflugt, som for eksempel muliggjort af et kunstværk, men en hel klasses flugt ud af et kriseramt klassesamfund. Postfascismen er det hvide småborgerskabs virkelighedsflugt, hvor den subjektive faktor overskrider det subjektive og bliver noget mere. Hvor manipulation bliver til entusiasme og bedrag til styrke og håb. Og vold selvfølgelig.

I forlængelse af Benjamin beskriver den tyske sociolog Oskar Negt og filminstruktøren og forfatteren Alexander Kluge fascismen som produktionen af en særlig fascistisk offentlighed, der er kendetegnet ved såvel en voldsom aktivitet og mobilisering som total politisk kontrol. Hverdagen blev pludselig scene for en konstant strøm af møder, marcher, parader og ceremonier, hvor nazipartiet mobiliserede befolkningen. Denne mobilisering gik hånd i hånd med styrets udstrakte brug af politisk vold, hvor den ariske races fjender blev fjernet på den ene eller den anden måde i overensstemmelse med førerens befalinger. Massen blev mobiliseret og formet af føreren. "Nationalsocialismen mobiliserer på en teknisk effektiv måde arbejdskraften som helhed, mens kapitalismen kun kan udnytte den delvist" (Negt og Kluge 172 (oversættelse korrigeret)). Det er en af forklaringerne på fascismens styrke, dens evne til at mobilisere hele samfundet eller hele arbejdskraften.

Fascismen løser krisen (men selvfølgelig ikke den grundlæggende modsætning mellem kapital og arbejde). Fascismen erstatter den revolutionære negation af kapitalismen med en myte om et oprindeligt nationalt fællesskab, der skal genskabes i kød og blod (og stål). ${ }^{3}$ Derved ophæves klassemodsætningerne på magisk vis og arbejderne kaster sig ud i opbygningen af et tysk tusindårsrige. Som Negt og Kluge skriver, forbliver ejendomsforholdene uantastet i fascismen, og arbejderne reproducerer de undertrykkende produktionsrelationer, arbejdskraft og mål adskilles i fascismen: arbejderne bidrager til produktionen af tusindårsriget og 'glemmer' den kommunistiske revolution.

Som den amerikanske værditeoretiker Moishe Postone skriver, er fascismens kunstgreb således at identificere kapitalismens revolutionære modernisering og traditionsafvikling med specifikke individer, nemlig jøderne (Postone). Jøderne bliver repræsentanter for det kapitalistiske samfunds modsætninger og klassekamp. Når jøderne er borte, er samfundets konflikter væk. Ophævelsen af den kapitalistiske økonomis ejendomsforhold erstattes med det nationale fællesskabs behov. Resultatet af denne usammenhængende antikapitalisme, hvor jøderne inkarnerer en international kommunistisk-kapitalistisk konspiration, som nazipartiet ikke blot skal bekæmpe, men decideret eliminere, er "kapitalisme uden kapitalisme" (Žižek i Herscher 60). Fascismen tilbyder en kritisk analyse af den moderne kapitalistiske verden, men identificerer kapitalens abstrakte, globale do-

3 Det er ganske karakteristisk, at det er udenlandsk stål, som Trump vil pålægge store toldafgifter. "Stål er stål, hvis du ikke har stål, har du ikke en nation," udtalte Trump på et pressemøde, da han præsenterede sine planer om at indføre toldafgifter. Stål er således et spørgsmål om national sikkerhed og 'sammenhængskraft'. At indføre told på stål er at beskytte det nationale fælleskab og holde det stærkt. Det er oplagt at læse dette som en latter day-version af den tyske fascismes stålromantik (Herf). 
24 KULTUR \& KLASSE $* 126 * 2018$ DET REAKTIONÆRE
25 MIKKEL BOLT

POSTFASCISMEN, ELLER DEN SENE KAPITALISMES KULTURELLE... minans med jøderne. Eliminationen af jøderne er for den tyske fascisme lig med ophævelsen af kapitalens abstrakte historiske kræfter. Som Žižek formulerer det i forlængelse af Postone, "fascismen ønsker at bevare kapitalismens grundlæggende forhold, men samtidig fjerne kapitalismens ideologiske og økonomiske træk. Idealet er at have kapitalisme i forstanden privat ejendomsret og kapital-arbejde-relationen, men en kapitalisme der er frigjort fra dens excesser: ingen klassekamp, men i stedet samarbejde mellem klasserne, ingen åndløse penge, men i stedet patriarkalske forhold, hvor kapitalisten ikke er en åndløs udbytter, men en som tager sig af arbejderne på en patriarkalsk og faderlig måde" (60).

Som både Postone og Žižek pointerer, ophæver forestillingen om nationen selvfølgelig ikke de grundlæggende sociale og økonomiske modsætninger, men forener dem blot på et formelt niveau. Men det kan næsten se ud, som om modsætningerne ophæves, da modsætningerne hele tiden er i bevægelse og skifter plads. Nogle gange forsøger Trump at lægge bånd på Wall Street og kritisere finanskapitalen voldsomt, andre gange giver han banker og virksomheder enorme skattelettelser. Trumps evne til hele tiden at skifte mening udstyrer hans politik med indtryk af dynamik eller uforudsigelighed, selvom den er helt statisk. Men sådan ser det ikke ud. Det ser anderledes ud, det ser ud, som om der er gang i den. Som om Trump er ved at genskabe amerikansk storhed. Han lægger sig ud med den politiske elite, dele af administrationen, medierne og alle mulige overnationale institutioner. Det ser ud, som om der bliver lavet om på det hele, at der er ved at blive skabt en ny virkelighed. Det er måske pointen med de "alternative facts". Men bag al virakken og opløsningen af distinktionen mellem facts og alternative facts forbliver de grundlæggende modsætninger selvfølgelig uløste. Trump kan ikke gøre noget som helst ved det lange forfald, USA har været konfronteret med siden 1970'ernes begyndelse. Kursen er sat, Trump har blot øget farten, nu sker kollisionen lidt hurtigere, Trump forkorter 'det amerikanske århundrede'.

\section{SENKAPITALISME OG KRISE}

Jamesons analyse af postmodernismen, som jeg startede med, er mestendels en analyse af postmodernismen som en kulturel logik. Han analyserer ar- kitektur, installationskunst, film og filosofi som elementer i en ny kulturel formation, der har afløst modernismen. Analysen af de postmodernistiske artefakter og værker finder imidlertid sted som en del af en bredere analyse af senkapitalismen. Det er selvfølgelig derfor, Jameson vælger den programmatiske titel, der aktiverer den marxistiske basis-overbygningsmodel, hvor kulturelle udtryk analyseres i forhold til en økonomisk basis. De føres ikke på nogen reduktiv måde tilbage til basis hos Jameson, kulturen er ikke blot en afspejling af basis, men de kan naturligvis heller ikke analyseres 'formalistisk', løsrevet fra basis. Jamesons greb er at bruge basis-overbygningsmodellen i en analyse af kulturelle udtryk, der umiddelbart har sluppet deres forankring i historien og ikke længere lever op til tidligere forestillinger om nyhed og brud. Der er således en kompleks dobbelthed af diskontinuitet og kontinuitet i Jamesons analyse. Han forsøger at komme på højde med en udvikling, hvor økonomien er blevet kulturaliseret og vice versa.

Umiddelbart er det selvfølgelig diskontinuiteten, der er det afgørende - Jameson går fra monopolkapitalisme til senkapitalisme og fra modernisme til postmodernisme, han vil bidrage til en analyse af en ny periode. Men som det fremgår af hans terminologi, er der om ikke andet $\mathrm{i}$ basis tale om kontinuitet. Det er senkapitalismen, ikke postkapitalismen, han analyserer. Som det fremgik af titlen, skulle postmodernismen forstås i relation til ændringer i den kapitalistiske produktionsmåde. I modsætning til Lyotard og andre, der forstod postmodernitet som en afsked med den kapitalistiske modernitet og marxismen (som den kritiske analyse af den kapitalistiske modernitet), så insisterede Jameson på at analysere postmodernismen i forlængelse af en (marxistisk) økonomikritik af kapitalismen. Kapitalismen havde, som Mandel viste i sin afhandling, ganske vist ændret sig, den var nu i sin tredje fase, men den var stadigvæk kendetegnet ved grundlæggende modsætninger, der ikke var blevet overvundet. Det var også udgangspunktet for Jamesons diagnose.

Som allerede angivet, må en analyse af samtidens postfascistiske fænomener også nødvendigvis handle om kapitalisme, om sammenhængen mellem fascisme og kapitalisme, men også om forholdet mellem kultur og økonomi (i en kriseramt kapitalisme). I den resterende del af teksten vil jeg derfor udvide analysen af postfascismen og forsøge at skitsere den 'bagvedliggende’ økonomihistoriske udvikling, der er baggrunden for genkomsten 
af fascisme i Vesten, altså beskrive hvad jeg i forlængelse af Jameson (og Adorno og Mandel) kalder den sene kapitalisme (med alle de suspekte deterministiske betydninger, det implicerer - krise og død (men selvfølgelig også utopiske implikationer - postkapitalisme, kommunisme, hvem ved, man har jo lov at håbe...)). I en udvidet og mere sammensat basis-overbygnings-model skal der stadigvæk redegøres for den ‘økonomiske’ udvikling.

Som jeg skrev, er postfascismens 'sandhed' krisen, at den globale kapital har været i krise siden sidst i 1960'erne og begyndelsen af 1970'erne. Krisen har faktisk været der hele tiden, og der har da også løbende været sammenbrud, men krisen har for en stor dels vedkommende (i Vesten) været skjult under enorme mængde fiktiv kapital samt bolig- og dot.com-bobler. Men tendensen er klar: økonomierne trækker sig sammen og kan slet ikke indoptage nye arbejdere, det er den situation, som postfascismen skal håndtere. De nye fascistiske fænomener skal ses på baggrund af den økonomiske krise, der ramte verdensøkonomien i forlængelse af finanskrisen i 2007, men som går tilbage til sidst i 1960'erne.

\section{HINSIDES KOMPROMIS}

Fra Brexit til Trump til Orban har løsningen på den økonomiske krise og synliggørelsen af en voldsomt voksende ulighed været nationalisme på en måde, de fleste ville have forsvoret for 20 år siden. Da kreditboblen sprang, og regeringer verden over nationaliserede gældsposterne og skruede op for spareprogrammerne, blev mennesker ikke blot skubbet ud af økonomien, mistede deres job, måtte gå fra hus og hjem eller blev frataget understøttelser af forskellig art. Denne udvikling understregede en allerede igangværende omlægning af efterkrigstidens løn-produktivitets-kompromis, hvor der i mere end tre årtier er blevet sparet på den sociale reproduktion (Aranowitz og DiFazio; Neel). Der er sket et enormt fald i reallønninger i lande som USA, Tyskland og Frankrig siden begyndelsen af 1970'erne. Det er sket, alt imens kapitalistklassen har tilegnet sig en stadig større del af samfundets værdi (Harvey). Den økonomiske krise skal således anskues som et moment i en længere historisk udvikling, der har været kendetegnet ved et vedvarende fald i de avancerede økonomiers vækst, hvad den amerikanske historiker Bob Brenner kalder "den lange tilbagegang” (Brenner).
27 MIKKEL BOLT

POSTFASCISMEN, ELLER DEN SENE KAPITALISMES KULTURELLE...

Det er selvfølgelig historien om den neoliberale globalisering, der har udhulet efterkrigstidens nationale socialstat, som den etablerede arbejderbevægelse (og de revolutionære socialister) tvang de lokale kapitalistklasser til at etablere i perioden efter 1917. Oktoberrevolutionen i Rusland lancerede truslen om et gennemgribende opgør med kapitalismen, dens udbytning og fremmedgørelse. Det blev derfor altafgørende for kapitalismen i den efterfølgende periode at afbøje denne trussel og integrere arbejderne i nationalstatens politiske fællesskab (efter at millioner af arbejdere havde slagtet hinanden i Anden Verdenskrigs blodbad, som den italienske venstrekommunist Amadeo Bordiga konkluderede (Bordiga)). Som den engelske historiker Eric Hobsbawm skriver, var "Ekstremernes århundrede" bestemt af konflikten mellem kommunisme og kapitalisme (Hobsbawm), og efterkrigstidens industrielle demokrati var en politisk-økonomisk løsning, der skulle redde kapitalismen og forvandle den kommunistiske trussel til kollektive aftaler, velfærd og konsum. Operationen lykkedes ovenud, og den vestlige arbejderbevægelse mistede såvel forbindelsen til filosofi som til det revolutionære perspektiv i midten af 1930'erne. Den italienske politiske filosof Antonio Negri beskriver denne proces som en "konstitutionalisering af arbejdet", hvor "kapitalen organiserer arbejderklassen" og "organiserer sig i arbejderklassen" (Negri, "Costituzione" 31-41). Arbejderklassen negerer sig selv som arbejderklasse og "styrer sig selv inden for rammerne af den kapitalistiske produktion som arbejdskraft" (40).

I maj '68 blev velfærdsstatsløsningen imidlertid udfordret af nye militante subjekter, kvinder, migranter og unge, der hverken passede til det socialstatslige fordistiske løn-produktivitets-kompromis eller til marxismens klassepolitik, hvor den mandlige industriarbejder var normen. Unge proletarer, kvinder og migrantarbejdere udgjorde, hvad Karl-Heinz Roth har kaldt "den anden arbejderbevægelse", der ikke blot afviste socialstaten, men også de socialdemokratiske og stalinistiske partier og fagforeninger og den idé om klasse og arbejde, som de abonnerede på (Roth).

Svaret på maj '68 kom imidlertid prompte i form af det, vi i dag kalder den neoliberale globalisering. Neoliberalismen eller globaliseringen var den gradvise afvikling af det nationaldemokratiske velfærdsstatskompromis, hvor den herskende orden i Vesten og USA havde lukket luften ud af arbejderbevægelsens revolutionære trussel. Mod at blive anerkendt som 
legitime politiske subjekter og få adgang til forbrug og velfærd skruede arbejderbevægelsen ned for sin kritik af det kapitalistiske samfund og indgik en aftale om arbejdsmarkedsadgang. Det er fortællingen om arbejderbevægelsens sejr, men også historien om dens nederlag (Eley, Forging Democracy; Endnotes 70-192). Historien om hvordan det delvist lykkedes at tæmme kapitalens despotisme i den første og den anden verden i perioden efter 1945 og frem til slutningen af 1970'erne, men det er naturligvis også fortællingen om neutraliseringen af den vestlige arbejderklasse og om dens totale opgivelse af international solidaritet og klassekamp (Linden og Thorpe 18).

Som den ungarske filosof G.M. Tamás skriver, var nationalisme prisen for få adgang til politisk lighed, kortere arbejdstid, bedre arbejdsvilkår, højere lønninger, betalte ferier, gratis uddannelser og billigere boliger (Tamás 124). Med socialdemokratiske partier ved roret i den første verden og statskapitalistiske stalinister i den anden verden blev kampen mod udbytning, undertrykkelse og ideologi erstattet af nationale moderniseringskampagner, hvor arbejderklasserne blev til befolkninger og objekter for biopolitisk styring (Foucault). Fagforeninger blev en del af staten, og socialistisk internationalisme blev langsomt afløst af nationale fællesskabsfølelser og idéen om 'det fælles gode', hvor fælles blev forstået som national enhed. Det er denne dyrt købte adgang til de nationale politiske fællesskaber, der nu igen hjemsøger arbejderklasserne og muliggør fascistiske løsninger på krisen og forvandler velfærdschauvinisme til en mere direkte voldelig eksklusion.

Det er Vestens nationaldemokratiske velfærdssystem, der er i krise. Den neoliberale globalisering har undermineret de nationale socialstater, der blev etableret efter Anden Verdenskrig. Skabelsen af et globalt arbejdsmarked har udfordret klassealliancen mellem lokale arbejderklasser og lokale, men i stigende grad transnationale kapitalistklasser, og derfor sker der nu et racistisk backlash, hvor en stor del af de hvide arbejdere i lande som USA, Frankrig, Tyskland og Danmark kræver deres ret og vil have staten til at sikre deres privilegier. Efterkrigstidens demokratiske velfærdsstat er væk. Den keynesianske løsning er en del af fortiden, der er ikke nogen New Deal, som Negri formulerer det (Negri, "No New Deal"). $\mathrm{Nu}$ eksisterer den blot som en tom skal, politikere henviser til. Som en del
29 MIKKEL BOLT

POSTFASCISMEN, ELLER DEN SENE KAPITALISMES KULTURELLE...

af en zombie-modernitet, hvad Jameson kaldte postmodernismen, hvor institutioner og former, der for længst er tømt for indhold og har overlevet sig selv, fortsat eksisterer i form af det parlamentariske demokrati eller kunstinstitutionen. Postfascismen er et forsøg på at standse denne tømning og give den en ny form, men postfascismen accelererer blot opløsningen, og krisen uddybes. Velkommen til postmodernismen, hvor utopien er en tilbagevenden til 1950'ernes post-utopiske tid.

MIKKEL BOLT. Lektor ved Institut for Kunst- og Kulturvidenskab, Københavns Universitet. Han har skrevet en række bøger, deriblandt Trumps kontrarevolution (Nemo, 2017, engelsk udgave Trump's Counter-Revolution (Zero, 2018), fransk oversættelse La contre-révolution de Trump (Éditions Divergences, 2019)), Hegel after Occupy (Sternberg Press, 2018) og After the Great Refusal: Essays on Contemporary Art, its Contradictions and Difficulties (Zero, 2018).

\section{POSTFASCISM, OR, THE CULTURAL LOGIC OF LATE CAPITALISM}

Postfascism is very much a cultural phenomenon. And the conflicts of today occur less as class struggle than as cultural battles. Why is that? I propose to use Fred Jameson's classic text on postmodernism (as the cultural logic of late capitalism) as a framework for considering the new postfascist tendencies that have emerged during the last few years in USA and Europe (Trump, Brexit, Alternative for Germany, Pegida, Le Pen, Wilders' Party for Freedom, the Danish People's Party etc.). Jameson's analysis of postmodernism supplies us with a 'take' with which we can start mapping these reactionary or postfascist phenomena and embed them in an analysis of changes in late capitalism.

\section{KEYWORDS}

DA: postfascisme; Trump, Donald J.; Brexit; postmodernisme; Jameson, Fredric EN: Post-fascism; Trump, Donald J.; Brexit; Postmodernism; Jameson, Fredric.

\section{LITTERATUR}

Aranowitz, Stanley og William DiFazio. The Jobless Future. Minneapolis: University of Minnesota Press, 2010. 
30 KULTUR \& KLASSE $* 126 * 2018$ DET REAKTIONÆRE
31 MIKKEL BOLT

POSTFASCISMEN, ELLER DEN SENE KAPITALISMES KULTURELLE...
Benjamin, Walter. "Kunstværket i dets tekniske reproducerbarheds tidsalder" ["Das Kunstwerk im Zeitalter seiner technischen Reproduzierbarkeit, 1936], oversat af Jørgen Holmgaard. Walter Benjamin. Kulturkritiske essays. København: Gyldendal, 1998. 129-158.

Bloch, Ernst. "Kritik der Propaganda". Vom Hasard zur Katastrophe. Politische Autsätze 1934-1939. Frankfurt: Suhrkamp, 1972. 195-205.

Bolt, Mikkel. Krise til opstand. Noter om det igangværende sammenbrud. Aarhus: Antipyrine, 2015.

Bolt, Mikkel. Trumps kontrarevolution. København: Nemo, 2017.

Bolt, Mikkel. "Benjamin og Trump. Fascisme, kontrarevolution og æstetiseringen af det politiske". Agora. Journal for metafysisk spekulasjon 2-3 (2017): 250-283.

Bordiga, Amadeo. “Guerra e rivoluzione" [1950], http://www.sinistra.net/lib/bas/battag/ ceka/cekafdezui.html

Braun, Emily. Mario Sironi and Italian Modernism: Art and Politics under Fascism. Cambridge: Cambridge University Press, 2000.

Brenner, Robert. The Economics of Global Turbulence: The Advanced Economies from Long Boom to Long Downturn, 1945-2005. London \& New York: Verso, 2006.

Debord, Guy. Skuespilsamfundet [La Société du Spectacle, 1967], oversat af Ole Klitgaard. København: Rhodos, 1972

Deleuze, Gilles og Félix Guattari. Tusind Plateauer. Kapitalisme og skizofreni [Mille Plateaux. Capitalisme et schizophrénie 2, 1980], oversat af Niels Lyngsø. København: Det Kongelige Danske Kunstakademis Billedkunstskoler, 2005.

Eley, Geoff. Forging Democracy: The History of the Left in Europe, 1850-2000. New York: Oxford University Press, 2002.

Eley, Geoff. "Fascism Then and Now". Socialist Register 2016: The Politics of the Right. Red. Greg Albo og Leo Panitch. London: The Merlin Press, 2015. 91-117.

Endnotes. "A History of Separation". Endnotes 4 (2015): 70-192.

Eribon, Didier. Retour à Reims. Paris: Fayard, 2009.

Fassin, Éric. Populisme: Le grand ressentiment. Paris: Textuel, 2017.

Faye, Jean-Pierre. Théorie du récit. Introduction aux 'Langagaes totalitaires'. Paris: Hermann, 1972

Foucault, Michel. Sikkerhed, territorium, befolkning. Forelæsninger på Collège de France, 19771978 [Sécurité, territoire, population. Cours au Collège de France, 1977-1978, 2004], oversat af Peer F. Bundgaard og Carsten Sestoft. København: Hans Reitzels Forlag, 2008.

Ghosh, Jayati. "Globalization and the End of the Labor Aristocracy". Dollars \& Sense 329 (2017): 15-24.

Grossberg, Lawrence. Under the Cover of Chaos: Trump and the Battle for the American Right. London \& New York: Pluto Press, 2018.

Hansen, Mogens Herman. Hvordan forvrænger populismen demokratiet? København: Informations Forlag, 2017.

Harvey, David. A Brief History of Neoliberalism. Oxford: Oxford University Press, 2005.

Herf, Jeffrey. Reactionary Modernism: Technology, Culture, and Politics in Weimar and the Third Reich. Cambridge \& New York: Cambridge University Press, 1984.
Herscher, Andrew. "Everything Provokes Fascism. An Interview with Slavoj Zizek". Assemblage 33 (1997): 58-63.

Hewitt, Andres. Fascist Modernism: Aesthetics, Politics, and the Avant-Garde. Stanford: Stanford University Press, 1993.

Hobsbawm, Eric. Ekstremernes århundrede. Verdens historie 1914-94 [The Age of Extremes: The Short Twentieth Century, 1914-1991, 1994], oversat af Ole Lindegård Henriksen. København: Samleren, 1997.

Jameson, Fredric. Postmodernism, or, the Cultural Logic of Late Capitalism. London \& New York: Verso, 1991.

Jameson, Fredric. "The Aesthetics of Singularity". New Left Review 92 (2015): 101-132.

Laqueur, Walter. Fascism: Past, Present, and Future. Oxford: Oxford University Press, 1996

Leppert-Fögen, Annette. Den deklasserede klasse. Studier i småborgerskabets historie og ideologi [Die deklassierte Klasse. Studien zur Geschichte und Ideologie des Kleinbürgertums, 1974], oversat af Kirsten Amstrup, Flemming Olsen og Carsten Jensen. Kongerslev: GMT, 1976.

Linden, Marcel van der og Wayne Thorpe. "The Rise and Fall of Revolutionary Syndicalism". Revolutionary Syndicalism: An International Perspective. Red. Marcel van der Linden og Wayne Thorpe. Aldershot: Scolar Press, 1990. 1-24.

Lütticken, Sven. “Who Makes the Nazis?". e-flux journal 76 (2016). http://www.e-flux.com/ journal/76/69408/who-makes-the-nazis/

Lütticken, Sven. "Cultural Marxists Like US". Upubliceret manus, 2018.

Mandel, Ernst. Der Spätkapitalismus. Versuch einer marxistischen Erklärung. Frankfurt: Suhrkamp, 1972.

Manow, Philip. Im Schatten des Königs. Die politische Anatomie demokratischer Repräsentation. Frankfurt: Suhrkamp, 2008.

Mayer, Arno. "The Lower Middle Class as Historical Problem". The Journal of Modern History 47: 3 (1974): 409-436.

McKinsey Global Institute. Poorer than Their Parents? Flat or falling incomes in advanced economies, 2016 https://www.mckinsey.com/ /media/McKinsey/Global\%20Themes/ Employment\%20and\%20Growth/Poorer\%20than\%20their\%20parents\%20A\%2O new\%2operspective\%20on\%20income\%20inequality/MGI-Poorer-than-their-parents-Flat-or-falling-incomes-in-advanced-economies-Full-report.ashx

Müller, Jan Werner. Hvad er populisme? Et essay [Was ist Populismus? Ein Essay, 2016], oversat af Hans-Jørgen Birkmose. København: Informations Forlag, 2016.

Nagle, Angela. Kill All Normies: Online Culture Wars From 4Chan and Tumbr to Trumo and the Alt-Right. Winchester: Zero Books, 2017.

Neel, Phil A. Hinterland: America's New Landscape of Class and Conflict. London: Reaktion Books, 2018.

Negt, Oskar og Alexander Kluge. Offentlighet og erfaring. Til organisasjonsanalysen av borgerlig og proletarisk offentlighet [Öffentlichkeit und Erfahrung. Zur Organisationsanalyse von bürgerlicher und proletarischer Öffentlichkeit, 1972], oversat af Rolf Reitan. Grenå: NSU, 1974

Negri, Antonio. "Il lavoro nella Costituzione". Antonio Negri. La forma stato. Per la critica dell'economia politica della Costituzione. Milano: Feltrinelli, 1977. 27-110. 
Negri, Antonio. "No New Deal is Possible". Radical Philosophy 155 (2009): 2-5.

Postone, Moishe. "Anti-Semitism and National Socialism: Notes on the German Reaction to 'Holocaust'". New German Critique 19: 1 (1980): 97-115.

Reich, Wilhelm. Fascismens massepsykologi [Die Massenpsychologie des Faschismus, 1933], oversat af Vagn Christensen og Fleming Røgilds. København: Rhodos, 1974.

Retort. Afflicted Powers: Capital and Spectacle in a New Age of War. London \& New York: Verso, 2005.

Roth, Karl-Heinz. Den 'anden' arbejderbevægelse og den kapitalistiske repressions udvikling fra 1880 til i dag [Die 'andere' Arbeiterbewegung und die Entwicklung der kapitalistischen Repression von 1880 bis zur Gegenwart, 1974], oversat af Svend Halse. Kongerslev: GMT, 1976.

Seeßlen, George. Trump! Populismus als Politik. Berlin: Bertz + Fischer, 2017.

Stollmann, Rainer. "Faschistische Politik als Gesamtkunstwerk. Tendenzen der Ästhetisierung des politischen Lebens im Nationalsozialismus". Die deutsche Litteratur im Dritten Reich. Red. Horst Denkler og Karl Prümm. Stuttgart: Reclam, 1976. 83-101.

Taibbi, Matt. Insane Clown President: Dispatches from the 2016 Circus. New York: Spiegel \& Grau, 2017.

Tamás, G.M. "Ethnicism after Nationalism: The Roots of the New European Right". Socialist Register 2016: The Politics of the Right. Red. Greg Albo og Leo Panitch. London: The Merlin Press, 2015. 118-135.

Thalheimer, August. "Om fascismen" ["Über den Faschismus”, 1928], oversat af Henning Vangsgård. Fascisme og kapitalisme. Teorier om fascismens opståen og funktion. Red. Ib Thiersen. København: Tiderne Skifter, 1975. 94-118.

Toscano, Alberto. "Notes on Late Fascism". 2017 http://www.historicalmaterialism.org/ blog/notes-late-fascism

Traverso, Enzo. Les nouveaux visages du fascisme. Paris: Textuel, 2017.

Trotskij, Leon. "Borgerskabet, småborgerskabet og proletariatet?" [1932], oversat af Vagn Rasmussen et al. København: Socialistisk Arbejderforlag, 1993. 43-48.

Wright Mills, Charles. White Collar: The American Middle Class [1951]. Oxford: Oxford University Press, 2002. 